\title{
Smoldering Plasma Cell Myeloma
}

National Cancer Institute

\section{Source}

National Cancer Institute. Smoldering Plasma Cell Myeloma. NCI Thesaurus. Code

C7149.

A plasma cell myeloma lacking clinical manifestations and organ impairment. 